\title{
SLC16A4 Gene
}

National Cancer Institute

\section{Source}

National Cancer Institute. SLC16A4 Gene. NCI Thesaurus. Code C107463.

This gene plays a role in monocarboxylate transport. 